\section{SOI: $1.1 /$ TAS $\quad$ DOI: $10.15863 /$ TAS \\ International Scientific Journal Theoretical \& Applied Science}

p-ISSN: 2308-4944 (print) $\quad$ e-ISSN: 2409-0085 (online)

Year: $2015 \quad$ Issue: 03 Volume: 23

Published: $30.03 .2015 \quad$ http://T-Science.org
Sergey Iosifovich Tatarinov candidate of historical Sciences, associate Professor, Educational and Scientific Professional Pedagogical Institute of Ukrainian Engineering and Pedagogical Academy, Ukraine, Donetsk region, Artemovsk city brodiaga-art@ukr.net

SECTION 13. Geography. History. Oceanology. Meteorology.

\title{
THE ROLE OF DISTRICT COUNCIL OF DONBASS IN THE CREATION OF THE FIRST UKRAINIAN VOCATIONAL SCHOOL IN BAKHMUT
}

\footnotetext{
Abstract: The activities of the first vocational school in Bakhmut of Ekaterinoslav gubernia are for the first time studied in the article. It was the first institution of its kind in Russia and Ukraine,

The school was opened in 1895. The educational and vocational curriculum was developed by its pedagogical staff. The director-inspector P.A. Zhyrov headed the teachers. The teaching was linked with the needs of the Donbas industry by the various methodical receptions used by teachers.

There also was a contingent of so-called "trainees". They were trained technical professions without the general education cycle.

The school had a good production basis which included a forge, workshops, laboratories and a library.

Students produced various machine tools, furniture and tools during their vocational training in the workshops. Then all that was sold through the school's shop.

The Bakhmut school became the prototype of vocational schools of the Soviet period.

Key words: student, master, teacher, trainee, inspector.

Language: Russian

Citation: Tatarinov SI (2015) THE ROLE OF DISTRICT COUNCIL OF DONBASS IN THE CREATION OF THE FIRST UKRAINIAN VOCATIONAL SCHOOL IN BAKHMUT. ISJ Theoretical \& Applied Science 03 (23): 159-167.
}

Soi: http://s-o-i.org/1.1/TAS*03(23)27 Doi: crossef http://dx.doi.org/10.15863/TAS.2015.03.23.27

\section{РОЛЬ ЗЕМСКИХ ОРГАНОВ ДОНБАССА В СОЗДАНИИ ПЕРВОГО В УКРАИНЕ РЕМЕСЛЕННОГО УЧИЛИЩА БАХМУТА}

Аннотация: В статье впервые исследуется деятельность первого ремесленного училища в Бахмуте Екатеринославской губернии как первого учебного заведения этого типа в России и Украине.

Училище стало функиионировать с 1895 г. Педагогический коллектив под руководством директораинспектора П.А.Жирова разработал учебные программы образовательных и профессиональных дисииплин.

Применялись различные методические приемы связи преподавания с потребностями промышленности Донбасса.

Существовал контингент т.н. "практикантов" по обучению техническим профессиям без общеобразовательного цикла.

Училище имело основательную производственную базу, мастерские, кузнииу, лаборатории, библиотеку.

В ходе профессионального обучения в мастерских ученики изготавливали различные станки, мебель, инструменты на продажу через училищный магазин.

Бахмутское училище стало прообразом существовавщих в советское время профессиональнотехнических училищ.

Ключевые слова: ученик, мастер, преподаватель, практикант, инспектор

Сложившаяся сегодня в Украине сложная ситуация c подготовкой

ISPC The Best of European Innovations,

Gothenburg, Sweden высококвалифицированных кадров рабочих и технических профессий, упадок существовавшей 
при советской власти профессиональнотехнических училищ требуют переосмысления и использования опыта функционирования ремесленных училищ в России и Украине в конце 19-начале 20 столетий.

Бизнес в Украине мало заинтересован в подготовке кадров для производственных мощностей рудников, электростанций, металлургических и машиностроительных заводов, горно-добывающей промышленности. Фактически разрушена система планирования и размещения госзаказов на высококвалифицированных рабочих, бизнес не выступает заказчиком.

Поэтому профессионально-педагогическое сообщество должно обратить свое внимание на изучение, анализ и использование опыта первых ремесленных училищ в Украине в соответствии с требованиями времени.

При подготовке исследования авторы использовали печатные издания Бахмутской городской Думы, уездной земской управы, архивные материалы Днепропетровского, Одесского архивов, РГИА (Петербург).

В 1890 г. Предводитель уездного дворянства А. А. Карпов обратился к министру государственных имуществ об открытии среднего горно-заводского промышленного училища "..для развития горно-заводской промышленности в крае".

Управа направила перечень угольных, соляных рудников, заводов, горного производства Бахмутського уезда [1].

Одновременно министру народного образования Голова Бахмута В.И. Першин писал, что "местность около Бахмута изобилует разнообразными минеральными богатствами (соль, каменный уголь, киноварь, железная, медная, серебряно-оловянная руды)".

Много рудников и заводов "находятся в заведовании людей, которые не получили никакой научной подготовки", которая создает угрозу «жизни самих рудников".

По мнению В.И. Першина, решить многие проблемы могли бы руководители со специальным техническим образованием. Аналогичное письмо-ходатайство об открытии училища В.И. Першин, А. И. Горяинов, М. Р. Степанов 13 марта 1891 г. направили директору народных училищ Екатеринославской губернии [2-3].

Земский землемер И.П. Ильин отмечал, что "Бахмутський уезд и его окрестности принадлежат к степному пространству и имеют достаточно развитое сельское хозяйство и скотоводство, но хозяйство "из-за отсутствия специалистов велось плохо, из года в год, из поколения в поколение" [4].

В 1894 г. Николай II дал распоряжение министерствам финансов, государственных имуществ, народного образования открыть 7 средних технических, 15 низших технических и 17 ремесленных училищ по всей империи. На эту цель ежегодно из государственного бюджета выделялось I млн. рублей.

По распоряжению министра народного образования графа Делянова было образовано Особое совещание при руководителе Отделом промышленных училищ во главе с тайным советником Аноповим [5].

Oсобое совещание тайного советника Анопова и правительственного чиновника Минфина действительного статского советника Григорьева вело журнал, из которого мы можем получить сведения о характере обсуждения вопроса об открытии училищ. На совещании решали, строить ли училища из кирпича или дерева, одно или двухэтажные, иметь ли мастерской и, даже, где и сколько разместить клозетов.

Совещание пришло к выводу, что "в Бахмуте при местных условиях не представляется возможным строить деревянные сооружения., открытие здесь училища вызывается настоятельной необходимостью".

Бахмутской городской Думе приказано было "приступить к строительству здания ремесленного училища весной (1895), чтобы открыть к 1 июля 1896" [5].

Одновременно строительство училищ началось в Санкт-Петербурге, Ростове, Томске, Ташкенте, Царицыне, Рыбинске.

К установленному сроку было построено только училище в Бахмуте. В этом немалая заслуга В.И. Першина. 1 июля 1896 года училище было открыто [6; 7].

Здание училища было из красного кирпича, 2-этажное, с оригинальной архитектурой. До 2-х этажного здания было пристроено два одноэтажных здания - мастерские.

Генеральным подрядчиком ремесленного училища был бахмутский купец Моисеев, который оказался не опытным в строительном деле и нечистым на руку.

Для контроля над ходом строительства училища Дума образовала Строительный комитет.Председатель и члены этого комитета вели две тетради расходов и актов.

После завершения строительства было выявлено огромное количество недоработок, дефектов и откровенной кражи денег.

Во время строительства член строительной комиссии, будущий директор-инспектор 
П.А. Жиров и инженер Карл Квельмс, обращали внимание в своих письмах Екатеринославскому губернатору на многочисленные отклонения от проекта купца Моисеева. Невнимательность к этой проблеме в губернии сказалась на контроле над ходом строительства ремесленного училища $[10 ; 11]$.

В декабре 1898 вице-губернатор А. Михайлов отмечал, что "ремесленное училище, только построенное за казенный счет в Бахмуте и уже занято учениками, вряд ли может быть признано прочным и достаточно пригодным для своего назначения".

Младший ревизор Екатеринославского казначейства Полтавченко в акте в ноябре 1897 обнаружил, что "стены в пол-кирпича вместо положенных по смете в один кирпич вряд ли будут крепкие при воздействии парового котла и машин".

Была образована комиссия по проверке здания училища во главе с губернским инженером статским советником Харманським, в составе Л. Бродницкого, О. Фейгина, младшего инженера А. Миклошевського, А. Аршеневського, исправника уезда В.Мельникова, городского архитектора Любимова [10;11].

Комиссия в течение двух месяцев работала и выявила многочисленные нарушения и отступления от проекта. Все фундаменты и стены одноэтажного здания были выполнены не из Дружковского кирпича, а из бутового камня. Причем, Моисеев почему-то покупал камень по 14 рублей за 1 м3, как и кирпич (кража). Самовольно подрядчик заменил 18 голландских печей на центральное отопление с калориферами, с двумя котельными. Попечитель учебного округа и министерство разрешения не давали. На сумму более 15000 рублей отсутствовали акты, документы о приобретении материалов и выполнения работ. Это был факт бесспорной кражи подрядчиком, но наказание никто не понес, деньги в городскую казну возвращены не были 6.

Попечитель Одесского учебного округа, признал работы удовлетворительными, но акт об этом исчез. Взятые пробы раствора кладки стен училища были отправлены на анализ в Институт инженеров путей сообщения, но результат так до Бахмута и не дошел [6-7].

Специализированная комиссия в 1899 г., организованная управлением Екатеринославской губернии после осмотра здания признала его непрочным, а стены признали опасными, принимая во внимание результаты химанализов растворов для кладки здания училища.

Архитектор Мазиров доложил, что он осматривал училище несколько раз в 1897, 1898 гг. Он уверял, что здание было выстроено прочно и может быть признано устойчивым, но не отрицал, что химический раствор действительно был неудовлетворительный и не соответствовал требованиям. В 1898 году при осмотре управляющим промышленных училищ советником Аноповым, архитектор Мазиров "ударял несколько раз по стенам большим кузнечным молотом и стены оказались вполне устойчивыми" [9].

На совещании 28 июля 1899 года под председательством попечителя, на котором присутствовали окружной инспектор Филоматитский, окружной архитектор Мазиров, статский советник Рябков, окружной юристконсультант Геникес обсуждался вопрос о качестве постройки Бахмутского ремесленного училища.

Попечитель утверждал, что "даже плохой химический состав раствора не может пересилить тот факт, что здание находилось в отличном состоянии и за два года после его постройки отстутвовали какие либо объективные данные, которые указывали на непрочность здания", «в виду противоречий между положением о растоврах и имеющихся фактов и мнений, просил строительную комиссию осмотреть все здание и донести, если ли где то трещины или повреждения, и если они найдутся то дать архитектору Мазирову возможность их исправить, если проверка строительной коммисси будет положительным, то они готовы представить все это на усмотрениме Министерства народного просвещения и произвести осмотр здания и дать окончательное заключение о его прочности, с чем согласились все члены совещения" [10].

24 октября 1897 главой Попечительского Совета стал городской Председатель В.И. Першин.

Училище имело 36 помещений. Земельный участок размером 2600 саженей Думой была передан в собственность училища. В училище были квартира директора-инспектора П.А. Жирова, 3 классных комнаты, рисовальная комната, слесарный класс, литейная мастерская, машинная, кузница. Общая стоимость оборудования - 14 тыс. руб.

В первый год на содержание училища было отпущено 10568 руб., На приобретение оборудования - 9023 руб. Общее финансирование училища осуществляло министерство образования (11379 руб.), Из бюджета городской Думы (1000 руб.), От учебного округа (100 руб.), Плата за обучение (550 руб.), От доходов за заказы и от продажи работ учащихся $[10 ; 11]$. 
В первый год обучения в училище было в столярно-токарном отделении 7 учеников (из них 2 практиканта), в слесарном отделении - 44 ученика (из них 2 практиканта).

Занятия в училище проходили по 6-дневке, с 8 до 12 часов - уроки в классах, с 12.30 до 17.00 практические занятия в мастерских. С 1 по 15 июня каждого года была практика в мастерских училища и на предприятиях Бахмута. Учебный год длился с 1 сентября по 30 мая. Плата за обучение составляла 10 руб. в год, 1/7 часть учились бесплатно из-за бедности $[10 ; 11]$.

Учебная нагрузка ремесленного училища состояла из еженедельных часов физики, арифметики с счетоводством, начертательной геометрии, чистописания, русского языка, литературы, физики, основ технологии обработки дерева и металла, довольно много часов рисования и пения.

Учебная программа и планы были примерными, изменения и дополнения в них вносились преподаватели $[9 ; 11]$.

Учебниками для преподавания предметов служили: по Закону Божьему учебник Соколова, по русскому языку "Этимология и синтаксис" Кирпичникова, "Родной язык" Соколова, по арифметике и счетоводству - "Задачи" Малинина, "Арифметика" Голубова, "Фабричный курс счетоводства" Плотникова, "Геометрия" Вуллиха, "Физика для городских училищ" Малинина.

В училище существовала богатая библиотека. Если в 1896 году в библиотеке было книг технического содержания - 53, пособий и учебников для учащихся - 286, в кабинете черчение, рисование и технологии -101 книга и пособие, то в 1902 году книг технического и технологического содержания было - 171 , учебников и пособий для учеников - 378 , периодических изданий газет и журналов - 64, пособий по чистописанию - 33. В кабинете черчения и рисования было 217 пособий, таблиц, альбомов.

Уже в момент открытия училища инспектор П.А. Жиров ставил перед начальством вопрос о необходимости оборудовать физический кабинет [11].

Ежегодно на приобретение приборов выделялось от 500 до 1000 руб.

В 1901 году Министерство Народного образования выделило 2 тыс. руб. на дооборудование физического кабинета. Инспектор П.А. Жиров пожертвовал самой большой комнатой своей небольшой квартиры.

В физическом кабинете насчитывалось 192 приборов и наглядных пособий, среди которых немало таких, о которых многие нынешние учителей мало что и знают. Физкабинет имел лабораторию [12].

Общежития и пансиона в училище не было. Иногородние учились за плату от 6 до 10 руб. в год, проживали в домах бездетных горожан и бедняков.

С момента открытия и до Февральской революции директором был Петр Афанасьевич Жиров, родившийся в 1850 г., статский советник, окончил Петербургский университет в 1878 , преподавал арифметику, геометрию, счетоводство, физику. Имел недельную нагрузку 12 часов. За многолетний труд в училище был награжден орденами св. Станислава и Анны. Вероятно, пользовался большим авторитетом в губернском правлении, поскольку в 1902 году возглавлял комиссию по приему новых зданий механико-технического училища в Мариуполе и среднетехнического училища в Александровске. П.А. Жиров был членом Совета училищ уезда, активным общественным деятелем - одним из основателей Бахмутского музыкальнодраматического общества, участником самодеятельных спектаклей в Народном Доме.

В обязанности инспектора училища входило посещение уроков других учителей. В отчете за 1901-1902 гг. П.А. Жиров отмечает, что посещал уроки черчения и русского языка, делал замечания об отступлениях от программ, на педсовете "разбирались наиболее подходящие для ремесленных училищ методы и способы преподавания". В училище по инициативе учителя физики более подробно изучали машины с переменным давлением пара, устройство паровоза - для будущих помощников машинистов. Подробнее изучались динамомашины, методы измерения единиц тока - для будущих машинистов электростанций и подъемных машин шахт. При изучении арифметики задачи составляли на расчеты состава растворов для будущих работников солеварных и содовых заводов Бахмутского уезда. Математик П. А. Жиров осуществлял "связь преподавания с жизнью" (веяния 50-х годов XX века).

Впервые в курсе технологии металлов были введены понятия об устройстве доменных, пудлинговых и сталеплавильных печей, "вызывается местным характером промышленной деятельности" - отмечал П.А. Жиров [10;11].

П.А.Жирова как прекрасного педагога и руководителя, общественного деятеля Бахмута были завистники и недоброжелатели на самом высоком городском уровне.

В переписке с директором народных училищ Екатеринославской губернии инспектор Жиров "в виду серьезности обвинений в его сторону, 
считал свои долгов изложить обстоятельства и причины, породивших слухи". Жиров утверждал, что "за завтраком у городского головы Першина, на котором присутствовали представитель земской управы Карпов директор народных училищ, были обвинения в сторону инспектора Жирова. Карпов и Першин имеют с ним личные счеты по поводу постройки Бахмутского ремесленного училища. История этой постройки породила к нему крайнее озлобление, как главному виновнику выявленных дефектов и недостатков постройки. Озлобление затем было усиленно столкновениями при постройке народной аудитории, постройке каменной ограды по периметру училища. Особая ненависть была со стороны Першина". Жиров утверждал, что ненавить "проявлялась не только лично к нему, а и была направлена против интересов ремесленного училища" [9].

Жиров писал, что "господа Карпов и Першин не имеют никакой связи с ремесленным училищем, вышли из состава членов Попечительного совета, выход сопровождался письменным заявлением Першина, что он обижен" [11].

Жиров утверждал, что "правильное суждение о жизни училища и его сотрудниках может дать только Попечительский совет этого училища, члены которого живут в г. Бахмут и имеют постоянный контакт с ремесленным училищем".

После выхода из Попечительского совета, А.А.Карпов, как представитель земской управы, самовольно лишил училище 1000 руб. земского пособия за 1902 год, "Першин заявил, что половина училищной усадьбы будет отобрана Думой" [9].

Першин и Карпов распространяли слухи по городу о личности Жирова, чтобы "вызвать негатив и неприятные инциденты в жизни училища".

Жиров утверждал, что "преподавательский состав училища, никогда не жаловался и не сообщал ему плохих вестей про их образ жизни в училище" [9].

В письме Попечителю Одесского Учебного округа от директора народных училищ было подтверждено, что "обвинение против инспектора ремесленного училища в злоупотребление спиртными напитками, являются следствием личных счетов с некоторыми из местных представителей власти..употребление спиртных напитков г. Жировым, не давало поводов, что он злоупотреблял ими" [13].

Директор училищ отметил, что "учебное дело в училище поставлено вполне удовлетворительно, училище пользуется хорошей репутацией, инспектор Жиров в служебном отношении ни разу в течение 7 лет совместной службы, не давал повода быть им недовольным".

Значительное место педагогический коллектив училища уделял анализу воспитанности учащихся: проблемой было влияние семьи на учащихся, поскольку они очень много времени находились в училище, а родители, в свою очередь, были заняты промышленными и торговыми делами.

По поводу нарушений поведения родителей приглашали в училище.

Из 105 учеников в 1902 году имели "5" по поведению -101, "4" - только 3. Среди поступков - проделки и "лишняя живость соответственно возрасту, драки друг с другом, лень, непреднамеренная порча имущества, пропуски занятий".

П.А. Жиров отмечал, что "ученики имеют слабые стремления к самообразованию путем внеклассного чтения, умственное развитие посредственное".

В выпускном классе, по мнению врача Стебельского, физическое развитие значительно опережало умственное, "нравственное состояние учеников дает основания желать лучшего" [10].

Почетным смотрителем (по нынешним временам это глава государственной экзаменационной комиссии) был директор Брянцевский соляной шахте горный инженер коллежский советник Михаил Николаевич Лямин, родившийся в 1861 г., закончил Горный институт, имел ордена св.Анны и Станислава.

Священник Покровской церкви Платон Никифорович Шумов был законоучителем.

Среди преподавателей в 1902 году учитель Высшего народного училища К.А. Прохватилова, преподаватель русского языка и чистописания, M.M. Смельницький - преподаватель русского языка, Н.И. Мазурин - преподаватель рисования.

Н.И. Мазурин родился в 1871, закончил Строгановское художественное училище, служил в Орле и был оттуда приглашен в Бахмут. В фондах Артемовского краеведческого музея есть футляр чертежной готовальни Николая Мазурина, ученика 3-го класса Строгановского училища, врученный ему за успехи в рисовании в 1890 году.

Н.И. Мазурин в училище выполнял обязанности классного надзирателя (по нынешним временам - классный руководитель), заведовал библиотекой, был секретарем педагогического Совета.

В 1898-1902 гг. художественные работы ремесленников направил инспектор П.А. Жиров на Всероссийскую Промышленную выставку 
(вместе с промышленными изделиями, чертежами, фотографиями), в Академию живописи [10;11].

Возможно, ремесленное училище, было обязано именно Н.И. Мазурину за созданием прекрасной фотомастерской и одной из самых богатых в учебных заведениях Бахмуту библиотеки.

Заведующим мастерскими были Александр Николаевич Красковский, 1870 рождения, переехавший в Бахмут с Вольская, Константин Васильевич Орлов.

24 мая 1900 года инспектор Жиров ходатайствовал попечителю Одесского учебного округа "о выдаче пособий в 200 рублей каждому учителю рисования Николаю Мазурину и преподавателю черчения и технологии Константину Орлову для поездки в Париж для ознакомления со спецотделами всемирной выставки...это весьма полезно и крайне необходимо в интересах учебно-воспитательного дела" [14].

Учителем пения в училище был Г.А. Макогон, церковный регент и учитель пения Благовещенской ЦПШ.

Врачом училища был Владимир Максимилианович Стебельский. Секретарем училища служил Григорий Кузьмич Погорелов, 33 года, окончил в 1885 году Бахмутское городское училище [10; 11].

При училище существовал склад готовых изделий учащихся и магазин для продажи этих изделий.

Попечительский Совет планировал издать Каталог товаров, продаваемых в училище.

Любой житель города мог в училище заказать для себя те или иные изделия, инструменты, товары.

В 1902 году ученики выполнили на продажу малый сверлильный станок за 25 руб., счеты классные за 15 руб., полированную сундук, этажерки и полки для книг для горожан, столы для народной аудитории Народного Дома, тумбы-столы. Таких заказов было на 132 руб.

В магазине училища изготовленных учениками товаров было на 4546 руб. Были проданы сверлильный станок на чугунной базе за 150 руб., токарный по металлу ножной станок за 100 руб., много шаблонов, ключей гаечных инструмента.

Это позволило получить дополнительно в бюджет училища 342 руб.

Ученики выполняли заказы по литью из гипса различных изделий - статуэток, лепнины для домов.

Понятно, что все это было невозможно без хорошей материальной базы учебных мастерских, фотолаборатории, токарной, слесарной, литейной. В столярной мастерской были установлены 5 станков и 24 верстака, а для учащихся было 774 наборов инструментов. В слесарно-токарной мастерской были установлены действующие паровые машина и котел, 21 станок для обработки металла, напильников было 2303.

В кузнице ученики работали на пяти наковальнях, четырех мехах.

В столярной, слесарной мастерских были мастера-практики, машинист по обслуживанию паровых машин, кузнец и два молотобойцы [10; 11].

Для работы учащихся в мастерских ежегодно покупалось в больших количествах "железо различных сортов", сталь инструментальная, чугун, медь, олово, свинец и цинк в слитках, медь сырая десятками пудов. Приобретались и отдельные инструменты, метчики, развертки, ключи, кронциркули, клещи, скобели, гладилки, кувалды, детали машин [10; $11]$.

Сочетание учебного корпуса с мастерскими создавало определенные неудобства, поскольку "устройство уборных, мастерских и отсутствие раздевалок мешали поддерживать чистоту помещений и воздуха" - отмечал врач Стебельский.

Экзамены в училище проходили в конце мая. На них присутствовали Почетный смотритель Лямин, член Попечительского Совета инженер Д.Д. Ремпель - владелец металлолитейного завода [8; 9].

Училище давало высокую профессиональнотехническую подготовку. С 1 выпуска в 1899 (79 учеников и 21 практикант) в Штейгерские училища поступило 3 , на заводах и рудниках уезда работали 14 человек, в Одесское училище искусств поступил 1 выпускник.

Выпускники уже заранее были известны владельцам предприятий и рудников достаточной глубиной знаний и технической подготовки, поэтому рекомендации педагогического и Попечительского Совета попросили всего 5 выпускников [10; 11].

Педагоги и врач Стебельский внимательно следили за здоровьем учеников. За год ученики посетили врача и земскую амбулаторию в 840 случаях, лекарства получали бесплатно в городской аптеке.

В училище на несчастные случаи была аптечка первой помощи. Один ученик умер в больнице от воспаления почек. Наиболее часто ученики болели малярией (21 случай), гриппом и OP3 (31 случай), гастритом (12 случаев), ревматизмом (8 случаев), было много порезов, ожогов [10; 11]. 
В училище был жесткий отбор учеников при поступлении. В 1901 году из 71 желающих поступить 35 не были приняты из-за слабых знаний, был высокий отсев - до 19\% ежегодно (по желанию родителей и за неуспеваемость). На повторный курс было оставлено из 119 учеников31.

Социальный состав учащихся - детей торговцев и ремесленников - 40, служащих на фабриках и рудниках - 17 , из землевладельцев 17 , из семей чиновников - 3, из мещан 31. Училище в сословном плане ориентировалось на подготовку кадров для торгово-промышленной сферы. Из числа учеников было 16 евреев, 1 немец [10].

Проблемы, возникшие при приеме учеников, обострились в 1908 г.: большой наплыв, слабая подготовка выпускников церковно-приходских школ.

Подготовительный класс имел следующее расписание: Закон Божий - 2 часа, русский язык 4 часа, чистописание - 2 часа, арифметика - 4 часа, география и история - 2 часа, рисование - 2 часа, чертежи - 2 часа и еженедельная практика в мастерской - 18 часов [10].

Уже с начала работы училища шла дискуссия как о подготовительном классе, так и о роли практики, обучения т.н. "практикантов".

В переписке с Попечителю Одесского учебного округа инспектор Жиров писал, что Г. Плотницкий "выражал мнение по поводу недостаточности трехклассного курса обучения в ремесленном училище для прохождения учебной программы", и соглашался с тем, что "недостаток времени являлся следствием плохой подготовки поступающих".

"При большом спросе на ремесленное образование и при поверочном испытании для всех желающих поступить в училище, как это практикуется в Бахмутском ремесленном училище, согласно разрешению директору народных училищ Екатеринославской губернии от 27 августа 1898 г, всегда можно выбрать достаточно подготовленных мальчиков в том объеме познаний, который полагается для поступающих в 1 класс по уставу народных училищ и с тем развитием, которое соответствует объему познаний и возрасту".

"Считалось совершенно излишним томить детей ранее изученным материалом целый год в испытательном классе, только для того чтобы узнать пригодны ли они для обучения в ремесленном училище. Они не изучали ничего нового, а только повторяли то, что учили в народных школах".

"После годичного испытания многим из детей принятым без повторного испытания, придется отказать в дальнейшем обучении, как неспособным либо к науке либо к ремеслу. Между тем содержать детей год всегда сопряжено со значительными расходами для родителей".

Комиссия выявила "совершенное несоответствие по качеству и количеству учебного материала 1 класса ремесленного училища, тому возрасту и неизбежно с ним связанному развитию детей и объему их познаний и понятий, которые достигаются народной школой".

П.А.Жиров писал: "если сравнить знания поступающего в 1 класс ремесленного училища, с тем, что он должен знать в конце учебного года, то это сравнение поразит даже малоопытного учителя. Поэтому необходимо 1 класс ремесленного училища привести в согласие с объемом познаний и развитием народной школы, сделать этот класс непосредственным её продолжением, без чрезмерного объема новых понятий и знаний. Это можно достигнуть только переносом некоторых предметов во 2 класс и увеличением числа часов на прохождение остальных программ".

"Что касается соблазна, вызываемого существованием "практикантов", ни один исправный ученик не изъявил желания перейти в практиканты. Переходят обычно ученики, которые в силу разных обстоятельств крайне тяжело изучать научные предметы, о которых преподаватели того мнения, что им полезнее перейти в практиканты".

П.А.Жиров считал, что "нельзя согласиться c мнением, что практиканты вообще не желательны, для дела они очень полезны там, где принимаются заказы, при обучении практикантов ремеслу можно не придерживаться строго определенной программы и ставить их на дело, которое необходимо, требуется при заказах" [15].

Министр народного просвещения фон Кауфман с 7 июня по 17 ноября 1908 рассматривал ходатайство Думы об открытии подготовительного класса [10].

Вопрос был передан в Государственный Совет, бюджетную комиссию III-Й Государственной Думы, которая изучила вопрос по докладу депутата А.И. Куломзина. Расчет показывал, что на содержание подготовительного класса необходимо было 1,8 тыс. руб., - С платы за обучение 300 руб., С заработанных училищем средств - 600 руб., От Думы и земства - по 250 руб., От казначейства - 440 руб.

4 ноября 1908 Николай II наложил на Законе об открытии подготовительного курса в училище резолюцию "Быть по сему". 
В 1902 опекун училища В.И. Першин поставил перед министерством народного образования вопрос о создании электротехнического класса.

В переписке с Одесским учебным округом инспектор Жиров в июле 1904 года доложил, что «было предложено открыть горнопромышленное отделение при Бахмутском ремесленно училище, которое могло бы готовить инженеров и горных десятников.

Такое решение требовало предварительного одобрения городской Думы и уездного земства. Нужно было выработать подробные программы обучения, время их исполнения и формы занятий учащихся, узнать потребность в специалистах у заводов и предприятий горнопромышленников местного региона.
"Необходимость устройства в Бахмутском ремесленном училище горнопромышленного отделения связано "с жизненными интересами горной промышленности", Попечительский совет, включающий членов крупных горных предприятий, являются главным двигателем в осуществления этого проекта"- отмечал П.А.Жиров [16].

8 января 1908 г. Совет министров разрешил отпустить 46 тыс. руб. на строительство электротехнического класса - лаборатории, 79 тыс. руб. - на новую литейную мастерскую, 1,8 тыс. руб. - на две квартиры для смотрителей (классного руководителя) и служителя, а также строительство новых хозяйственных сооружений училища [17].

\section{References:}

1. (1890) Doklady Bakhmutskoy upravy i zhurnaly KHKHÍV ocherednogo sobraniya. Bakhmut, 1890, - 401 p.

2. (1893) Otchet Bakhmutskoy gorodskoy upravy za 1892. - Bakhmut, 1893. -113 p.

3. (1892) Khodataystvo Bakhmutskoy uyezdnoy Upravy ob otkrytii tekhnicheskogo uchilishcha v Bakhmute, 1892. RGIA. - F. 733. - Op. 161. - D. 57.

4. (1886) Sbornik statisticheskikh svedeniy po Yekaterinoslavskoy gubernii. Bakhmutskiy uyezd, t.2. - Yekaterinoslav, 1886, - 186 p.

5. (1894) Delo ob otkrytii semi novykh remeslennykh uchilishch $\mathrm{v}$ raznykh gorodakh Rossii, 1894. // RGIA. - F. 565. - Op. 4. - D. 17269.

6. (1897) Plany i fasad remeslennogo uchilishcha g. Bakhmuta; Doklady Bakhmutskoy uyezdnoy upravy i zhurnaly XXXÍ ocherednogo sobraniya. - Bakhmut, 1897, - 341 p. // RGIA. - F. 733. - Op. 224. - D. 178.

7. (1896) Otchet Bakhmutskoy gorodskoy upravy za 1896. // RGIA. - F. 573. - Op.30. - D. 1010

8. (1899) Otchet Bakhmutskoy gorodskoy upravy za 1899. // RGIA. - F. 1288. - Op. 6. - D. 84

9. (2015) Perepiska s Ministerstvom narodnogo prosveshcheniya o postroyke zdaniya dlya Bakhmutskogo remeslennogo uchilishcha. Kantselyariya popechitelya Odesskogo uchebnogo okruga. // Odesskiy obl.gos.arkhiv. - F. 42. - Op. 35. - arkh. №1041. - pp. 15-16.
10. (1917) Otchety o sostoyanii Bakhmutskogo remeslennogo uchilishcha za 1898-1916 // RGIA. - F.733. - D.d. 1791, 1792, 1793, 1794, 3470, 3472 .

11. Tatarinov SY, Fedotov SA (2012) Ístoríya pedagogíki ta narodnoî osvíti Donbasu /S.Y.Tatarinov //. - Kharkív: PP Machulín, 2012, -120 p.

12. (2015) Perepiska s uchrezhdeniyami po stroitel'no-remontnym rabotam i drugim voprosam Bakhmutskogo remeslennogo uchilishcha. Kantselyariya popechitelya Odesskogo uchebnogo okruga. // Odesskiy obl.gos.arkhiv - F.42. - Op.35, - arkh. №1209. - pp. 11-14.

13. (2015) Perepiska s uchrezhdeniyami po stroitel'no- remontnym rabotam i drugim voprosam Bakhmutskogo remeslennogo uchilishcha. Kantselyariya popechitelya Odesskogo uchebnogo okruga. // Odesskiy obl.gos.arkhiv. - F.42. - Op.35. arkh. №1209. - pp. 10.

14. (2015) Perepiska s Ministerstvom narodnogo prosveshcheniya i drugimi uchrezhdeniyami i litsami o Bakhmutskom remeslennom uchilishche. Kantselyariya popechitelya Odesskogo uchebnogo okruga. // Odesskiy obl.gos.arkhiv. - F.42. - Op.35, - arkh. №1092. - pp. 41.

15. (2015) Perepiska s Ministerstvom narodnogo prosveshcheniya i drugimi uchrezhdeniyami i litsami o Bakhmutskom remeslennom 
uchilishche. Kantselyariya popechitelya Odesskogo uchebnogo okruga. // Odesskiy obl.gos.arkhiv. - F.42. -Op.35. - arkh. №1092. - pp. 10-14.

16. (2015) Perepiska s uchrezhdeniyami po stroitel'no- remontnym rabotam i drugim voprosam Bakhmutskogo remeslennogo uchilishcha. Kantselyariya popechitelya Odesskogo uchebnogo okruga. // Odesskiy obl.gos.arkhiv. - F.42. - Op.35. - arkh. №1209. - pp. 15-16.

17. (1909) Otchet Bakhmutskoy uyezdnoy zemskoy upravy za 1908. - Bakhmut, 1909. - 103 p. 